\title{
TERRA, PODER E CAPITAL EM NOVA MUTUM-MT: ELEMENTOS PARA O DEBATE DA PRODUÇÃO DO ESPAÇO NAS “CIDADES DO AGRONEGÓCIO”
}

\author{
DANILO VOLOCHKO ${ }^{1}$ \\ Universidade Federal do Paraná
}

Resumo: A urbanização de regiões dinamizadas pelo agronegócio em Mato Grosso está articulada ao processo de produção do espaço agrário, à atuação patrimonialista do próprio Estado e à ação dos capitais agroindustriais e financeiros nacionais e internacionais. A concentração fundiária pressuposta na expansão dos latifúndios e das "modernas" propriedades do agronegócio envolve a constituição de um espaço-tempo - da produção das commodities agrícolas -, que se liga na escala intraurbana a mecanismos de controle de terras e valorização imobiliária através de atividades como planejamento urbano e loteamento. A pesquisa parte da realidade urbana e rural do município de Nova Mutum como possibilidade para compreender os processos produzidos na relação entre a dinâmica do campo modernizado pelo agronegócio e a produção do espaço urbano. A colonização privada - que marca uma historicidade monopolizada, dominada pela Mutum Agropecuária S.A. - articula-se à disputa pela reprodução atual do capital e do poder, entrelaçando o planejamento público municipal e os interesses fundiários privados. Analisamos como a elaboração recente do Plano Diretor dessa cidade vem sendo conduzida e que implicações esse instrumento de planejamento coloca para os negócios fundiários urbanos e para a reprodução de uma urbanização oligopolista cujos conteúdos podem atualizar a segregação socioespacial como fundamento da sociabilidade urbana.

Palavras-chave: Concentração Fundiária; Produção do Espaço; Agronegócio; Planejamento Urbano.

\section{LAND, POWER AND CAPITAL IN NOVA MUTUM-MT: ELEMENTS FOR THE DEBATE ON THE PRODUCTION OF SPACE IN "CITIES WITH AGRIBUSINESS"}

Abstract: The urbanization of regions invigorated by agribusiness in Mato Grosso is associated to the process of agrarian space production, the patrimonial activities of the state itself and the actions of agribusiness and national and international financial capital. The concentration of land expressed by the expansion of unproductive estates and of modern farms involves the constitution of a space-time -

\footnotetext{
${ }^{1}$ Professor do Departamento de Geografia da UFPR. Contato: danilo.volochko@ufpr.br.
} 
of the production of agricultural commodities - which is linked, at the intraurban scale, to land control and increasing property prices through activities such as urban planning and land divisions. This research is based on the urban and rural reality of the city of Nova Mutum as a possibility for understanding the processes resulting from the relation between the dynamic of the modernized agriculture and the production of urban space. Private colonization - which characterizes a monopolized history, dominated by Mutum Farming S.A. - is related to the dispute for today's reproduction of capital and power, intertwining municipal public planning and private land interests. We analyze how the recent elaboration of the Master Plan of this city has been conducted and what the implications of this planning instrument are for urban land deals and for the reproduction of an oligopolistic urbanization whose components renew socio-spatial segregation as a foundation of urban sociability.

Keywords: Land Concentration; Production of Space; Agribusiness; Urban Planning.

\section{Introdução}

A urbanização de regiões dinamizadas pelo agronegócio em Mato Grosso² nas últimas décadas apresenta elementos importantes para a compreensão da realidade social brasileira, pois está articulada ao novo e veloz processo de produção do espaço agrário - vinculado à expansão da fronteira agrícola dos anos 1970, redimensionada pelo agronegócio a partir dos anos 1990 -, à atuação patrimonialista do próprio Estado - em suas políticas de planejamento territorial e aos capitais agroindustriais e financeiros nacionais e internacionais, em sua reprodução geográfica desigual. A expansão das modernas atividades agrícolas ${ }^{3}$ nessas regiões tem envolvido a constituição de um novo espaço-tempo marcado por intensas transformações espaciais coordenadas pela lógica da produção de commodities agrícolas - sobretudo soja, milho, algodão e carnes processadas.

\footnotetext{
${ }^{2}$ Estado da Região Centro-Oeste do Brasil, que faz divisa nacional e internacional: a norte, com os estados do Amazonas e do Pará; a noroeste, com o estado de Rondônia; a sudoeste, com a Bolívia; a sul, com o estado de Mato Grosso do Sul; a sudeste e leste, com os estados de Goiás e Tocantins.

${ }^{3} \mathrm{O}$ debate sobre a modernização da agricultura é amplo e conta com extensa literatura. A discussão geral passa pela industrialização do campo e sua reestruturação produtiva, associada à complexificação da divisão do trabalho e a transformações nas bases técnicas da produção agropecuária com a integração dos setores agrícola, industrial, financeiro e de serviços (cf. DAVIS; GOLDEBERG, 1957, destacando-se o conceito de agribusiness). Esse debate desdobrou-se no Brasil, num primeiro momento, a partir da ideia da constituição dos chamados complexos agroindustriais (cf. SILVA, 1996), entendidos como a articulação de atividades ligadas à produção, beneficiamento e comercialização de produtos agropecuários, com utilização crescente de novas tecnologias (insumos, maquinários), forte papel do Estado em sua estruturação (incentivos fiscais, financiamentos) e vinculação intensiva aos capitais internacionais com a posterior dominação das grandes tradings mundiais (Bünge, ADM, Cargill, Louis Deyfrus etc.). De modo geral, a modernização da agricultura leva ao aumento da produtividade agrícola (sobretudo das commodities) e da participação desse setor no PIB nacional, compreendendo também importantes alterações nas relações de trabalho com a especialização crescente da mão de obra, assim como um processo de transformação socioespacial do campo e suas implicações para o modo como se reproduz.
} 
Tal dinâmica se liga, na escala intraurbana das "novas cidades" constituídas nas quatro últimas décadas, a mecanismos de controle e valorização de terras. A realidade urbana e rural do município de Nova Mutum ${ }^{4}$ coloca-se como possibilidade para compreender os processos decorrentes da relação entre o campo modernizado e a produção do espaço urbano a ele associado, no qual estratégias fundiárias são efetivadas e importantes relações sociais podem ser lidas no plano da vida cotidiana e da prática socioespacial urbana. Com isso tal realidade, ao mesmo tempo que expressa o crescimento econômico gerado pelo adensamento das cadeias produtivas movidas pelo agronegócio e suas relações com o desenvolvimento urbano, aponta também para uma renovada segregação socioespacial na base da sociabilidade e da produção do espaço nessas cidades.

$\mathrm{O}$ presente artigo resulta do desenvolvimento da pesquisa $A$ produção $d a$ periferia nas cidades do agronegócio ${ }^{5}$, que tem como um dos seus eixos o estudo da estrutura e da dinâmica fundiária em Nova Mutum e seus entrelaçamentos rurais-urbanos e público-privados mediados pela colonização privada, cujas implicações têm estado presentes na reprodução atual do capital e do poder. Isso é analisado aqui por meio de um instrumento de planejamento urbano municipal - o Plano Diretor (PD), que foi reelaborado em 2014 e sancionado em 2015. A metodologia utilizada para a operacionalização da pesquisa intercala a leitura bibliográfica com a realização de pesquisa de campo em Nova Mutum observação, registros, entrevistas semidirigidas ${ }^{6}$ e participação em audiências públicas sobre o PD -, além do levantamento de dados primários e secundários, de documentos oficiais/institucionais e corporativos/empresariais e também da elaboração de mapas.

O desdobramento da colonização privada - que marca a historicidade monopolista desta cidade, dominada pela empresa Mutum Agropecuária S.A. ${ }^{7}-$

${ }^{4}$ Cidade localizada a $250 \mathrm{~km}$ a norte da capital Cuiabá, nas margens da BR-163 (rodovia CuiabáSantarém). Adquiriu sua emancipação política em 1988 e sua população estimada em 2014, segundo o Instituto Brasileiro de Geografia e Estatística (IBGE), era de 38.206 habitantes.

5 Pesquisa iniciada em 2013 na Universidade Federal de Mato Grosso cujo objetivo geral é compreender os conteúdos socioespaciais da urbanização mais diretamente associados à expansão do agronegócio no estado de Mato Grosso, tendo como foco a análise de realidades intraurbanas e de processos, espaços e sujeitos que se constituem como o avesso do moderno, como "periférico" diante da centralidade instituída pela modernização do campo e das cidades.

${ }^{6}$ Foram realizadas até o momento 12 entrevistas com: moradores de Nova Mutum; trabalhadores de fazendas agropecuárias do município; o arquiteto da prefeitura responsável pela equipe de reelaboração do PD de Nova Mutum; a diretora do Conselho de Habitação da Secretaria Municipal de Assistência Social; o Secretário Municipal de Agricultura e Meio Ambiente; o Secretário Municipal de Indústria, Comércio e Turismo; o gerente do Grupo Mutum em Mato Grosso e um empresário do setor imobiliário atuante na cidade (Construtora Mega).

${ }^{7}$ De acordo com entrevista realizada com o gerente do Grupo Mutum em Mato Grosso e com o material do referido grupo disponível em seu sítio na internet http://www.grpart.com.br/, a Mutum Agropecuária S.A. faz parte do Grupo Mutum S.A. - um conjunto de empresas formado pela Mutum Agropecuária S.A., que atuou na colonização de Nova Mutum e que atua na incorporação de terrenos 
articula-se a um grande controle e concentração da terra, do poder e do capital, reproduzidos atualmente pelo entrelaçamento entre o planejamento público municipal e os interesses fundiários privados ligados ao agronegócio e que atualizam a produção da cidade e do urbano como um negócio imobiliário. De um lado, analisamos concretamente como a elaboração recente do PD (que é também denominado de Plano Diretor Participativo) de Nova Mutum vem sendo conduzida e que implicações esse instrumento urbanístico, legal e de planejamento coloca para os negócios fundiários urbanos - a exemplo da segurança jurídica para os fazendeiros/loteadores trazida pela ampliação do perímetro urbano e pelo novo zoneamento urbano. De outro, apontamos como uma urbanização de cunho oligopolista pode intensificar a constituição de processos de segregação socioespacial da população migrante formada por trabalhadores empobrecidos absorvidos pela atividade de processamento de carnes nos frigoríficos, dominada pela empresa de alimentos Brasil Foods (BRF) ${ }^{8}$. Vale destacar que esta empresa expressão da monopolização produtiva da commodity carne processada estabelece diversas parceirias com o poder público municipal, a exemplo da construção de conjuntos habitacionais para a moradia dos seus empregados, os quais, muitas vezes, acabam deixando o trabalho e passam a viver em cortiços e quitinetes procurando outras ocupações, geralmente no ramo da construção civil ou no trabalho braçal (em "serviços gerais", como limpeza de máquinas) em fazendas de grupos do agronegócio, como Vanguarda Agro, Bom Jesus, Amaggi, entre outras?.

A intensificação de cadeias produtivas financeirizadas por capitais nacionais e internacionais nas regiões dominadas pelo agronegócio dinamiza a produção do espaço em cidades que vão se configurando como importantes centros de execução de processos, normas e estratégias ligadas às atividades agrícolas modernas, mas

\footnotetext{
e na realização de loteamentos residenciais, comerciais e industriais na cidade; pela Mutum Agro, que atua na agricultura do município (cultivando, por exemplo, soja, milho, algodão e sorgo), na pecuária (bovinocultura), na psicultura (com o armazenamento de grãos e beneficiamento do algodão); e pela JAR Empreendimentos Imobiliários, que realiza a atividade de consultoria imobiliária para a Mutum Agropecuária S.A. O Grupo Mutum S.A. integra o GRP (Grupo Ribeiro Participações), que ainda possui empresas como a Praias Paulistas e Duas Anas (que atuam no litoral de São Paulo (Bertioga), no interior (Jundiaí, Campinas, Tatuí) assim como em outros estados, coordenando outras empresas ligadas a atividades de loteamento e incorporação (residencial, comercial, shopping centers, clubes de golfe, hotéis), psicultura e bovinocultura.

${ }^{8}$ Segundo nos informou o gerente da unidade produtiva da BRF em Nova Mutum em entrevista realizada em outubro de 2014, a empresa emprega no município 2.200 trabalhadores envolvidos no abate/processamento diário de 290 mil frangos. Para ele o Mato Grosso é estratégico para a empresa já que possui o menor custo de grãos de milho e soja, componentes básicos da ração e que constituem $70 \%$ do custo unitário da produção do frango. Como sintetiza: "não existe frango, existe milho transformado em proteína animal".

${ }^{9}$ Conforme informações obtidas em pesquisa de campo realizada em Nova Mutum.
} 
cuja centralidade encontra-se fora dessa região. ${ }^{10}$ As cidades localizadas no eixo da rodovia BR-163 (principalmente Nova Mutum, Lucas do Rio Verde e Sorriso) apresentam uma paisagem constituída por espaços altamente homogêneos e simétricos do ponto de vista do traçado e da morfologia urbana, configurando-se como forma de controle já que se impõe uma representação espacial do ordenamento, da lógica, da fluidez, do homogêneo, cuja arquitetura das edificações e urbanismo bastante padronizados lhes asseguram uma concepção de "cidade organizada", "cidade planejada", que se articula a uma estética do campo racionalizado pelas modernas estruturas de produção das commodities agrícolas.

Estudamos algumas das estratégias fundiárias do Grupo Mutum S.A. através da Mutum Agropecuária S.A., proprietária de grandes áreas de terra rural e urbana que, através do seu braço urbano - a JAR Empreendimentos Imobiliários - vem realizando juntamente com famílias que são grandes proprietárias de terra um controle oligopolista do direcionamento da expansão urbana através de doações, valorização e vendas (futuros loteamentos próprios ou de terceiros) de suas terras. Na medida em que a cidade deriva integralmente de um monopólio inicial de terras da Mutum Agropecuária S.A., o planejamento urbano municipal vem sendo influenciado pela lógica de um empreendedorismo imobiliário que conforma um mercado de terras oligopolizado sobretudo por esta empresa e pelas famílias proprietárias de terras.

O objetivo deste texto é trazer elementos da dinâmica fundiária e imobiliária nas "cidades do agronegócio" (cf. ELIAS, 2006) para que se possa elucidar as relações entre a terra, a produção do espaço e a reprodução do capital e do poder nesses contextos urbanos. Portanto, a crítica das "cidades do agronegócio" tem envolvido, nesta pesquisa, uma análise centrada no plano da produção do espaço intraurbano realizado pelos sujeitos sociais em suas ações econômicas, políticas (valorização do solo urbano e rural via políticas urbanas) e culturais (formas hegemônicas de representação do espaço); abarcando também a problematização das formas de sociabilidade nessas cidades - a segregação socioespacial como condição e resultado desses processos. Com base nessas preocupações, nosso plano de exposição percorre a análise dos fundamentos monopolistas da estruturação fundiária urbana e rural de Nova Mutum, das relações campo-cidade fusionadas pelo agronegócio, das relações entre esses fundamentos e o planejamento urbano através do PD e finaliza com algumas considerações sobre as implicações socioespaciais desses processos na vida urbana dessas cidades.

\footnotetext{
${ }^{10}$ Nos termos de uma divisão territorial do trabalho no Brasil as "cidades do agronegócio" matogrossense (Sorriso, Lucas do Rio Verde, Nova Mutum, Sinop, Campo Verde, Primavera do Leste, Rondonópolis, Sapezal, Campos de Júlio, Campo Novo do Parecis) polarizam regiões de produção agrícola cuja centralidade técnica, financeira, informacional e de gestão está localizada na Região Concentrada (cf. SANTOS, 2011).
} 


\section{Colonização e monopolização da terra: fundamentos da estrutura fundiária}

Embora a formação territorial da região onde hoje se localiza a cidade de Nova Mutum remonte à década de 1940 e ao ciclo da borracha e exploração das seringueiras, tratava-se de uma ocupação ainda incipiente feita por aberturas de caminhos em meio a fazendas para o escoamento do látex produzido e pela expulsão de tribos indígenas - como os Tapanhumas. É somente a partir do final da década de 1960 que o Estado, através dos governos militares, passa a subsidiar sistematicamente a apropriação da porção norte do Mato Grosso, sobretudo por meio de programas de incentivos fiscais para a instalação de projetos agrícolas, pecuários e agrominerais, da construção de infraestruturas básicas - como rodovias - e do processo de colonização das terras.

A construção da rodovia Cuiabá-Santarém (BR-163) significava a possibilidade de realizar a ocupação da pré-Amazônia mato-grossense, interligando o Centro-Sul do país à Amazônia, promovendo ao mesmo tempo a apropriação capitalista do território por meio de grandes projetos agropecuários que, economicamente inviáveis, serviram para a derrubada da floresta, a grilagem e a concentração das terras, a expulsão de posseiros e indígenas, a realização dos projetos (sobretudo particulares) de colonização e, por fim, à urbanização dessa região. O caráter monopolista que se desenhou para esta ocupação - dado pelo enorme poder econômico e político concentrado cada vez mais nas mãos de grupos empresariais e familiares (sobretudo do Centro-Sul do país) que começaram a adquirir terras e a tornarem-se grandes latifundiários com o incentivo do Estado a partir da década de 1970 - chega ao ponto de influenciar no próprio traçado da rodovia BR-163, cuja construção foi iniciada em 1971.

Diante da iminência da desvalorização de suas terras, as quais ficariam marginalizadas em relação ao traçado original da rodovia Cuiabá-Santarém, José Aparecido Ribeiro - que havia adquirido no município de Diamantino, em 1966, juntamente com empresários paulistas, uma vasta área de quase 170 mil ha e formado a Mutum Agropecuária S.A. para o desenvolvimento de projeto de pecuária (posteriormente plantação de arroz, milho e soja) com incentivos da SUDAM (Superintendência de Desenvolvimento da Amazônia) - teria acionado "pessoas influentes em Brasília, sobretudo o Deputado Federal por São Paulo, Herbert Levy e conseguiu alterar o traçado de asfaltamento da rodovia, possibilitando que em seguida Mutum, Tapurah, Lucas do Rio Verde e Sorriso fossem colonizadas na esteira da abertura da rodovia pelo atual e definitivo traçado" (SCHAEFER, 2002, p.20).

Neste contexto de apropriação monopolista da terra e da constituição de "grandes latifúndios" 11 em Mato Grosso, a Mutum Agropecuária S.A. destina 100

\footnotetext{
${ }^{11}$ A expressão "grandes latifúndios", embora possa remeter a um sentido pleonástico, expressa, de fato, a magnitude da concentração da terra em Mato Grosso e da desproporção do tamanho das
} 
mil hectares de suas terras para o desenvolvimento de projeto de colonização, uma vez que, contraditoriamente, a própria divisão de suas terras através da venda de lotes para a ocupação por agricultores vindos do sul do país realizaria a centralização necessária à valorização futura de suas propriedades tanto rurais como urbanas. Com isso, podemos afirmar que desde o início a perspectiva da produção da cidade e do urbano esteve colocada como condição e resultado de um processo de valorização fundiária agrícola, permitida pela concentração das terras e posterior organização do projeto de colonização.

Este processo tem sido contado pela sua versão mítica, personalizando na pessoa do "colonizador" José Aparecido Ribeiro todo o "pioneirismo" e "audácia" do visionarismo de um processo em verdade social e histórico que faz parte de um momento mais amplo de expansão - subvencionada por políticas públicas - da fronteira agrícola no Brasil. De fato, para Oliveira (1997, p.135) "historicamente, a colonização no Brasil tem se constituído na alternativa escolhida pelas classes dominantes para evitar, simultaneamente a necessária reforma estrutural do campo e (...) suprir-se de força de trabalho para seus projetos na fronteira". Segundo o mesmo autor,

Nesse aspecto estrutural, o Estado e o capital privado sempre deram as mãos. O capital privado, através da venda da terra aos camponeses, procura, por um lado, realizar, extrair a renda da terra e, por outro, simultaneamente, ir formando os 'viveiros de mão-de-obra' para seus projetos de exploração capitalista da terra. O Estado, por sua vez, tem ficado com a tarefa de buscar conter as tensões sociais e, nesse processo, tem feito dos projetos de colonização 'válvula de escape' das áreas de tensão social. Assim tem se dado historicamente a 'marcha para o Oeste' e a colonização na fronteira (OLIVEIRA, 1997, p.136).

O caráter latifundiário que se coloca na historicidade da produção do espaço agrário do norte mato-grossense, do qual o município de Nova Mutum faz parte e que significou a apropriação privada de extensas porções de terra por grandes fazendas de grãos e de gado, vem sendo constantemente reproduzido de diferentes maneiras. É preciso lembrar que este processo de apropriação de terras, na maior

propriedades que passaram a usufruir de incentivos fiscais naquele estado em comparação com os demais. Segundo Oliveira (1997, p. 296) "A área ocupada pelos projetos agropecuários e agrominerais na Amazônia Legal como um todo foi de mais de 9 milhões de hectares, sendo que a média da área desses projetos era de 7.000 ha no Amazonas, 14.100 ha em Tocantins, 16.300 ha no

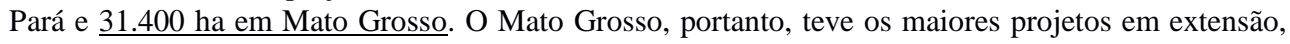
aprovados pela SUDAM" [grifo nosso]. O caso paradigmático parece ser o da Agropecuária SuiáMissu, em São Félix do Araguaia, cuja área aproximada era de 695.843 ha. Neste mesmo trabalho citado se analisa o porquê desses projetos possuírem um caráter latifundiário e patrimonialista. 
parte das vezes, se deu de modo ilegal com grilagens de terras públicas e particulares, com mecanismos de burla por meio da corrupção em órgãos públicos resultando na ocupação privada e ilegal de terras muitas vezes já discriminadas pelo INCRA (Instituto Nacional de Colonização e Reforma Agrária).

Segundo Moreno (2007, p.159), “a política de regularização fundiária, seguindo os fundamentos do Estatuto da Terra, foi utilizada pelos governos militares como o principal instrumento de 'reforma agrária' no país". Os projetos de colonização empresarial serviam como um mecanismo de regularização de terras, notadamente de transferência de terras devolutas para o domínio particular. Ainda segundo Moreno (2007, pp.163-164)

Para formalizar o processo, o Incra arrecadava grandes extensões de terras devolutas, após a realização do procedimento discriminatório, e procedia à 'licitação pública', dando preferência de compra ao empresário ocupante (...). Foi assim que diversos empresários do Centro-Sul do país tornaram-se também grandes proprietários de terra em Mato Grosso. Inicialmente 'ocupavam' as terras ao longo das rodovias federais (...), depois adquiriam-nas a preços simbólicos, justificado pela ocupação pioneira e desbravamento das áreas de cerrado ou floresta para a implantação da empresa capitalista. Para burlar a constituição no tamanho das áreas, recorriam a um 'procurador' que obtinha procurações de diversas pessoas, para requererem em nome de terceiros os títulos de propriedade das terras devolutas já ocupadas. (...). Ao Incra competia apenas sacramentar a ocupação, ou melhor, legalizar a grilagem titulando as terras onde normalmente eram desenvolvidos projetos agropecuários incentivados pelo governo.

De acordo com Moreno (2007), os projetos de colonização particulares ou empresariais absorviam agricultores mais capitalizados em áreas maiores, o que somado a uma série de dificuldades dos pequenos agricultores trazidos para os projetos de colonização oficial - entre elas pode-se destacar a "venda sistemática de lotes pelos parceleiros" (...), "a inacessibilidade ao crédito rural" (...) e "a falta de titulação das parcelas" (MORENO, 2007, p.171) - definiu o maior "sucesso" do tipo privado de colonização face à colonização oficial. Se o sentido da colonização historicamente desenvolvida no Brasil foi dado pela constituição da reprodução do capitalismo através de sua expansão territorial em direção aos interiores do país com a dominação do campo por meio da instituição das suas relações de produção e da concentração da terra para a necessária (e propalada) produção em escala elevada, é preciso ressaltar que houve, para Oliveira (1997), uma particularidade dada pela ocupação do centro-norte do Mato Grosso a partir da década de 1970 (OLIVEIRA, 1997, p.136), pois 
(...) nesta etapa recente da ocupação da Amazônia encontramos uma característica específica que se expressa no corte monopolista do processo. Isto quer dizer que o processo de ocupação recente traz consigo novas formas de atuação. Não estamos diante da lógica ditada pela disputa livre no mercado, dos interesses privados. Processo esse que comandou, por exemplo, a ocupação territorial do interior paulista e paranaense. (...). Na Amazônia, na atualidade, o processo tem a característica da fase monopolista do capitalismo. Estamos agora diante da lógica ditada por uma ação de monopólios privados ou públicos, não há mais disputa no e pelo mercado. Há tão somente a imposição dos monopólios. A mercadoria que comanda o processo de ocupação é a propriedade privada da terra.

Assim se colocam os termos dos fundamentos monopolistas da estrutura fundiária de Nova Mutum. Tal concentração da propriedade fica evidente quando considerados os dados de 2014 da Secretaria Municipal da Agricultura e Meio Ambiente. Segundo estes dados, as propriedades com tamanho superior a 1.000 hectares ocupam $74,83 \%$ da área total das propriedades do município e correspondem, por sua vez, a apenas $10,4 \%$ do número total de propriedades. Se considerarmos as propriedades acima de 500 hectares, vemos que estas ocupam $84,34 \%$ da área total das propriedades do município e correspondem a somente 17,84\% do número total. Esse caráter combina-se com uma dinâmica intensa e oligopolizada de produção imobiliária por meio da atividade de loteamento das grandes fazendas contíguas ao tecido urbano, em áreas de expansão urbana ou com perspectiva de integrar o novo perímetro urbano, conforme veremos. O Mapa 1 traz a situação fundiária do município de Nova Mutum tomando os dados de 2013. 


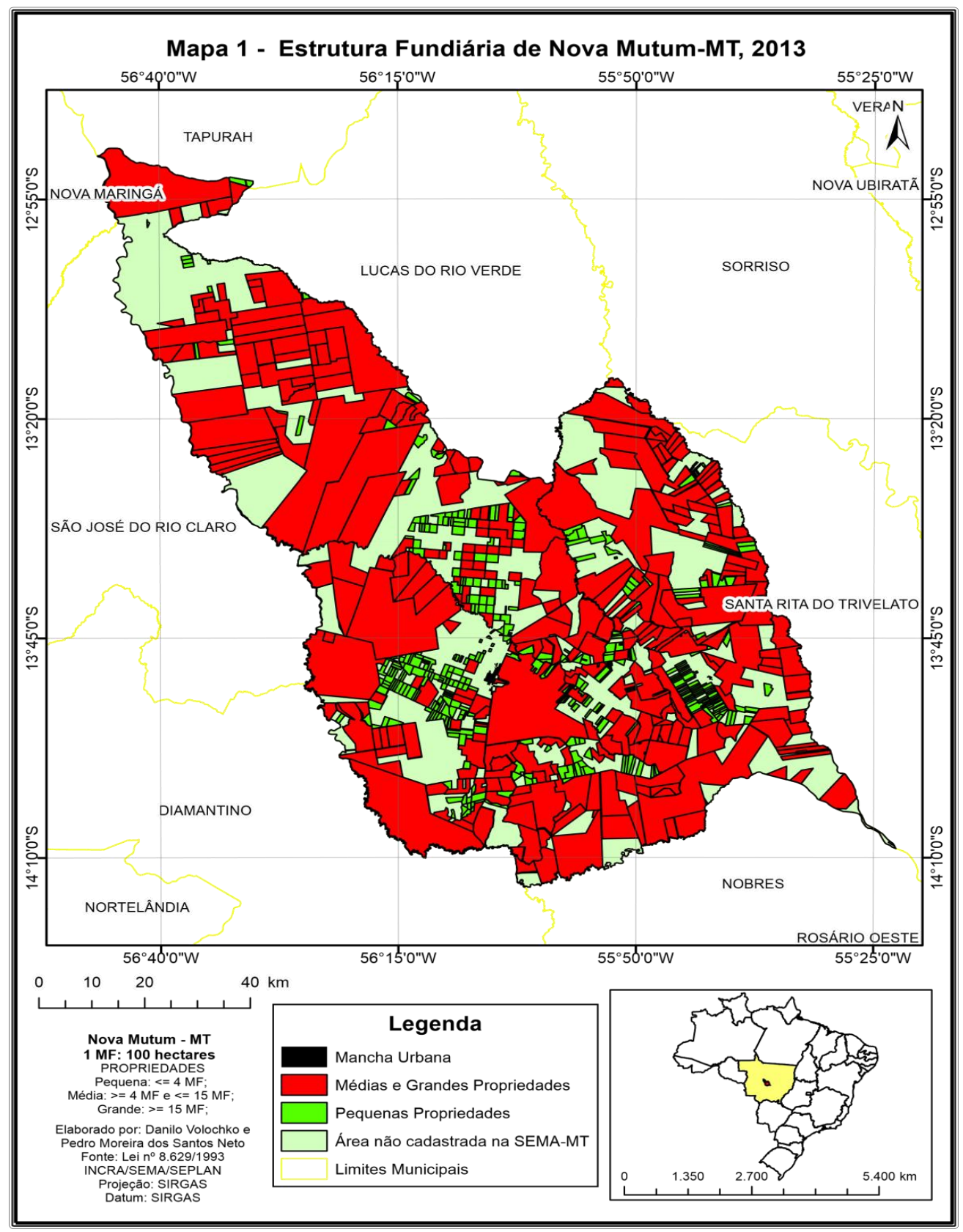


O Mapa 1 nos permite entender como estão divididas as propriedades rurais no município de Nova Mutum, destacando-se a cor vermelha, que representa as médias e grandes propriedades (acima de 400 hectares ou 4 módulos fiscais), que predominam e ocupam grande parte do território municipal, revelando a concentração da terra e da propriedade. A cor verde-limão representa as pequenas propriedades e o verde-claro representa as áreas que constam como não cadastradas nas bases de dados da Secretaria de Estado de Meio Ambiente (SEMAMT) e do INCRA. Não deixa de ser curioso que significativas extensões de terra do município de Nova Mutum estejam sem cadastro. Segundo a avaliação (com a qual concordamos) do geógrafo Pedro Moreira dos Santos Neto, coautor dos mapas, geralmente os proprietários fazem o cadastro das terras a fim de conseguir financiamentos em bancos para o custeio da produção agrícola. $O$ fato de ainda não terem feito o cadastro dessas áreas pode significar que elas estão em processo de cadastramento ou têm problemas de regularização - são terras devolutas ou públicas (do INCRA) griladas - ou, ainda, devido a algum provável passivo ambiental que poderia gerar multas aos pretensos proprietários.

\section{O caráter urbano do desenvolvimento da agropecuária modernizada}

A centralidade da cidade desempenha historicamente um importante papel de apoio ao desenvolvimento das atividades agrícolas e agropecuárias, seja da agricultura modernizada do atual agronegócio, seja da agricultura que se realizou e ainda se realiza no Brasil sob outras bases. Autores como Arruda (2007), Bernardes e Freire Filho (2006) e Elias (2006) vêm tratando de modo bastante consistente as relações entre a urbanização e as atividades ligadas ao agronegócio no plano do debate campo-cidade, sobretudo desde o ponto de vista da expansão do meio técnico-científico-informacional que leva a reestruturações produtivas do território, com reconfigurações das relações entre as cidades no âmbito de novas complexidades da rede urbana constituída por novos círculos de cooperação, circuitos espaciais de produção e especializações produtivas regionais. Assim, para Elias (2006):

Os elementos estruturantes destas novas relações são encontrados na expansão das novas relações de trabalho agropecuário, promovendo o êxodo rural (migração ascendente) e a migração descendente (SANTOS, 1993) de profissionais especializados no agronegócio; na difusão do consumo produtivo agrícola (SANTOS, 1988; ELIAS, 2003ab). Ao mesmo tempo, dinamizam o terciário e, consequentemente, a economia urbana, e evidenciam que é na cidade que se realiza a regulação, a gestão e a normatização das transformações 
verificadas nos pontos luminosos do espaço agrícola. (...). No período técnico-científico-informacional as cidades do agronegócio se multiplicam no país e passam a desempenhar muitas novas funções. Transformam-se, então, em lugares de todas as formas de cooperação erigidas pelo agronegócio globalizado, e resultam em muitas novas territorialidades. Se a cidade é a materialização das condições gerais de reprodução do capital (CARLOS, 2004), a cidade do agronegócio é aquela cujas funções de atendimento às demandas do agronegócio globalizado são hegemônicas sobre as demais funções.

Se por um lado as novas relações campo-cidade vêm sendo analisadas e esclarecidas, por outro pensamos que existem processos, relações e sujeitos que ainda carecem de análises mais aprofundadas, sobretudo quando consideramos o plano da produção do espaço a partir das estratégias e relações locais na escala intraurbana e no nível do cotidiano dessas cidades atravessadas pelo agronegócio. Com efeito, é necessário, por exemplo, que sejam esclarecidos os termos e relações entre a esfera pública e os interesses privados no tocante às dinâmicas fundiárias entre campo e cidade no sentido de considerar, como se refere Bernardes (2006), as diferentes temporalidades que marcam distintas espacialidades do avanço da agropecuária modernizada, definindo áreas concentradas/consolidadas da soja, áreas de expansão etc.

A colonização, sobretudo particular, do médio-norte mato-grossense está intrinsecamente ligada ao processo de concentração e monopolização da propriedade, condição para a reprodução capitalista no campo que traz muitas contradições, uma vez que esse processo carrega consigo "a necessária abertura dessa fronteira aos camponeses e demais trabalhadores do campo" (cf. OLIVEIRA, 1997, p.135). A especificidade da dinâmica da produção do espaço na região do médio-norte de Mato Grosso é que:

(...) a produção da cidade de certa forma se impõe ao campo, ainda que, propagandisticamente o campo possa estar sendo vendido primeiro (...). São as cidades que se impõem na Amazônia mato-grossense (...). Isso ocorre porque a economia brasileira ingressou na era dos monopólios, internacionalizou-se, mundializou-se (OLIVEIRA, 1997, p.137).

A lógica de produção do espaço urbano pressuposta na colonização empreendida pela Mutum Agropecuária S.A. aparece na concepção do plano urbanístico do núcleo urbano realizado entre 1977 e 1979 por empresas gaúchas ${ }^{12}$,

\footnotetext{
${ }^{12}$ Empresas Eldorado e Esplanid LTDA (Escritório de Planejamento de Irrigação e Drenagem).
} 
quando a Nova Mutum era ainda um distrito de Diamantino-MT. Inicialmente foram projetadas 116 quadras com 22 lotes em cada quadra e $1.000 \mathrm{~m}^{2}$ de área média por lote com o traçado tipo "tabuleiro de xadrez", tendo quadras retangulares e ruas largas. Mas o ponto fundamental que explica o caráter monopolista e urbano presente na expansão agropecuária é que a cidade surge de uma fazenda - e de uma única fazenda de apenas um proprietário: a Mutum Agropecuária S.A., à época comandada por José Aparecido Ribeiro. Ou seja, de uma só vez dispõe de quase 500 hectares de terra de um único proprietário, o que vai se diferenciar, por exemplo, do que ocorre em Lucas do Rio Verde, cuja colonização se deu a partir de projeto de assentamento do INCRA com módulos rurais menores, ou seja, de uma estrutura fundiária um pouco mais heterogênea. Então a colonização privada e monopolista de Nova Mutum favorece um controle e uma homogeneidade maiores em relação ao modo como o espaço foi sendo ocupado e produzido, o que se coloca como um fundamento de sua produção espacial que repercute na lógica do planejamento urbano, como será visto.

É nessa medida que o urbano e a cidade precedem o campo, criam as possibilidades do desenvolvimento do modelo capitalista neste, permitindo uma "modernização" das bases técnicas da produção com o agronegócio de modo combinado à recriação de arcaísmos como o latifúndio, a concentração da terra, a violência no campo e das relações de trabalho pautadas na superexploração dos trabalhadores, por vezes reproduzindo formas de trabalho escravo - como a peonagem ou escravidão por dívida, analisada por Martins (1999; 2012). Neste ponto torna-se indispensável esclarecer as distinções e relações entre os latifúndios e as "modernas" fazendas do agronegócio. Concordamos com Girardi (2008, pp.121-122) quando, baseado em outros autores, entende que

No caso da questão agrária brasileira, é indispensável considerar latifúndio e agronegócio como componentes de um mesmo território, pois, apesar de serem distintos, atuam conjuntamente no campo brasileiro no agravamento dos problemas agrários: um exclui pela improdutividade; o outro, pela superprodução. Latifúndio e agronegócio agem de forma cooperada. É (...) na fronteira agropecuária brasileira que a parceria entre latifúndio e agronegócio é mais evidente: o latifúndio precede o agronegócio, uma prática é substituída pela outra (...).

Assim, é comum tanto ao latifúndio - grande propriedade improdutiva ou pouco produtiva - quanto às fazendas produtivas da agropecuária modernizada a utilização de expedientes como grilagem de terra, exploração do trabalho, especulação fundiária e crimes ambientais (cf. GIRARDI, 2008, p.121). Do ponto de vista da dinâmica do capital em sua relação com a terra, vemos que "quanto mais concentrada for a terra, maior é o poder de extração da mais-valia em forma da renda da terra. Os grandes capitalistas (...) utilizam-na como reserva de valor 
para especulação (...)", assim como vemos que "latifúndio e agronegócio, para os quais a concentração da terra é indispensável, compõem a exploração capitalista no campo (...) a) através da especulação e compra antecipada da renda no latifúndio e b) pela apropriação da mais-valia no agronegócio" (GIRARDI, 2008, p.201).

Do mesmo modo os serviços urbanos e as modernas fazendas do agronegócio demandam uma mão de obra especializada - na condução de diversos processos mecanizados, cientificizados, de logística etc. -, na maioria das vezes a formação dessas fazendas, na situação de expansão da fronteira, é precedida da derrubada da mata e abertura de pastagens com utilização de trabalho braçal. E, com efeito, mesmo no momento da produção das commodities o trabalho braçal não é eliminado completamente, como ainda é mais requerido, haja vista, por exemplo, o trabalho pesado de limpeza das modernas máquinas agrícolas ${ }^{13}$. Nesta condição, a mão de obra é constituída, sobretudo, por trabalhadores pobres moradores das periferias de pequenas cidades economicamente deprimidas - muitas vezes filhos de camponeses e ex-garimpeiros - que migram em busca de trabalho, seja nos frigoríficos, seja nas fazendas do agronegócio. Indiretamente, todavia, a concentração da terra e a produtividade da agropecuária modernizada envolvem uma disputa com os camponeses, que muitas vezes têm de arrendar suas terras e perdem a autonomia.

O vínculo existente entre a expansão mais recente do agronegócio e a intensificação do crescimento urbano em Mato Grosso e em diversas regiões do país onde esta atividade se desenvolve expressa a realização tanto das dinâmicas concernentes à nova complexidade da divisão territorial do trabalho no plano das redes urbanas, como também revela o sentido da monopolização e da oligopolização da terra para a reprodução dos processos fundiários na interface entre o campo e a cidade, em que surge um campo crescentemente urbanizado e uma cidade que se expande sob poderes oligopolistas. Essa relação entre agronegócio e urbanização pode ser compreendida melhor, para o caso de Nova Mutum, tomando-se alguns dados, como aqueles que constam no Gráfico 1, no Gráfico 2 e na Tabela 1.

\footnotetext{
${ }^{13}$ Em aula de campo entrevistamos trabalhadores na colheita de algodão na Unidade de Produção Ribeiro do Céu (do Grupo Vanguarda Agro), em Nova Mutum. Seu trabalho consistia em limpar, de tempos em tempos e em curtos intervalos, as modernas colheitadeiras com enfardamento cilíndrico.
} 


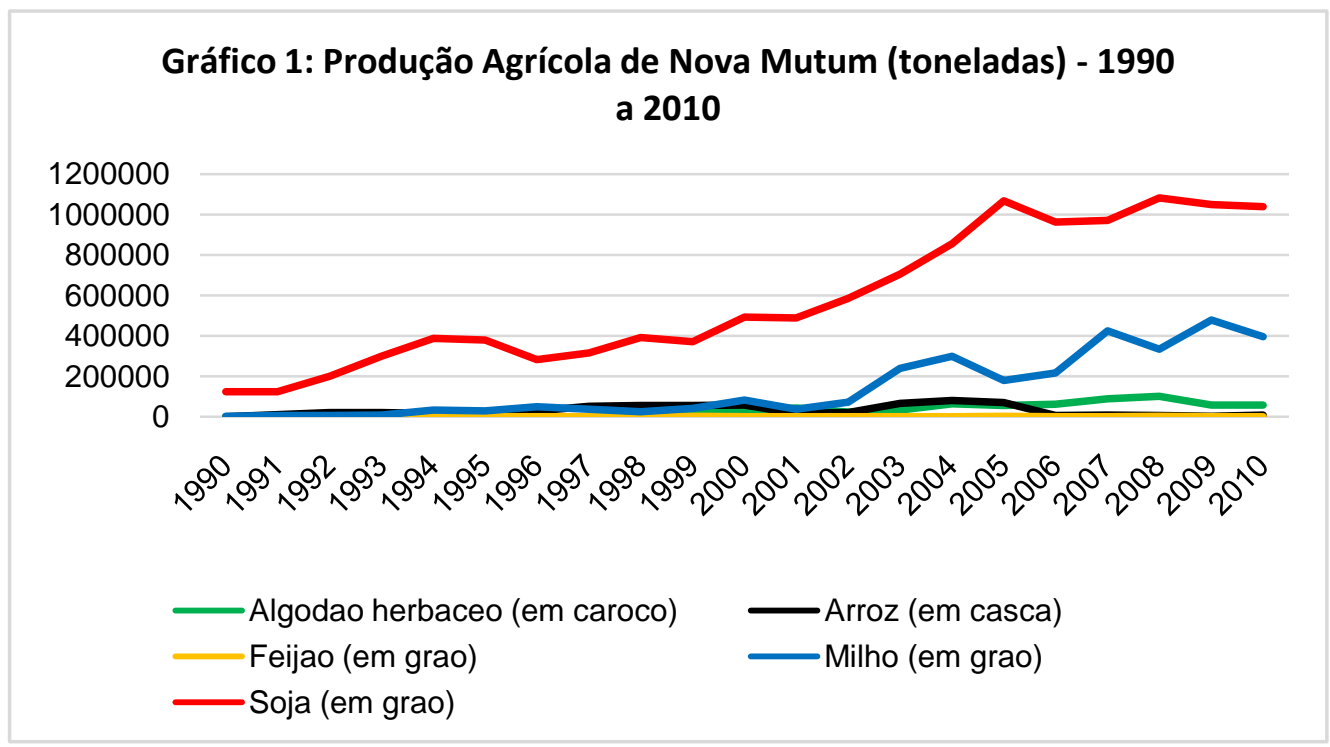

Fonte: IBGE - Produção Agrícola Municipal / Reelaboração: Danilo Volochko.

\section{Gráfico 2: Taxa média de crescimento populacional (\% a.a.) Nova Mutum, Mato Grosso e Brasil - 1991 a 2014} Brasil

Nova Mutum Mato Grosso

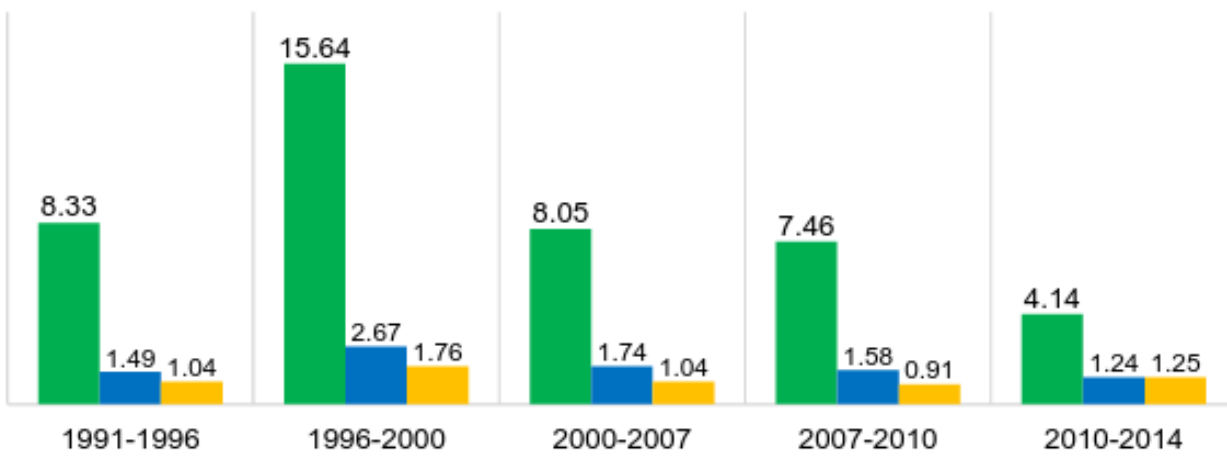

Fonte: IBGE - Censo Demográfico 1991, Contagem Populacional 1996, Censo Demográfico 2000, Contagem Populacional 2007 e Censo Demográfico 2010.

Elaboração: Danilo Volochko. 


\begin{tabular}{|c|c|c|c|}
\hline \multicolumn{4}{|c|}{ Nova Mutum: } \\
\hline População & 1991 & 2000 & 2010 \\
\hline Urbana & 37 & 72,02 & 81,72 \\
\hline Rural & 63 & 27,98 & 8,81 \\
\hline
\end{tabular}

Tabela 1: Nova Mutum - População urbana x rural.

Fonte: Atlas do Desenvolvimento Humano no Brasil - 2013.

É possível perceber a alta produtividade das commodities agrícolas soja e milho em Nova Mutum, às quais se poderia acrescentar a elevação do rebanho de suínos e, sobretudo, de aves. Ao mesmo tempo, uma taxa média de crescimento anual da população muito acima das médias do Mato Grosso e do Brasil, além de uma aceleração da urbanização da população. Isso evidencia como o crescimento urbano/populacional correlaciona-se com as atividades da agropecuária modernizada, fazendo-se necessário pensar em que bases o crescimento intraurbano tem se dado, o que será feito a seguir.

\section{Oligopolização do monopólio da terra, planejamento urbano e reprodução do poder político e econômico}

Como vimos, a ocupação monopolista da terra no eixo da BR-163 no centronorte mato-grossense derivou dos projetos particulares de colonização fomentados pelo governo federal. Tal processo significou, ao mesmo tempo e dialeticamente, um processo de oligopolização da terra - dado pela sua divisão/loteamento e colonização - para que se tornassem viáveis as atividades agropecuárias por meio do próprio crescimento dos núcleos urbanos, uma vez que estes centralizavam a demanda por infraestruturas, mão de obra e capital necessários para as atividades produtivas.

Se nas últimas décadas grandes grupos do agronegócio mundializado se instalam em Nova Mutum ${ }^{14}$, é preciso entender a historicidade deste movimento e seu modus operandi. Contando com a produção de arroz e soja de forma mecanizada desde o início do projeto da Mutum Agropecuária S.A. e com colonos, sobretudo do Rio Grande do Sul, "já capitalizados que adquiriam lotes de 50, 250 e 500 hectares" (OLIVEIRA, 1997, p. 355), a região foi propiciando a algumas famílias de produtores que começassem a acumular terra e capital, a exemplo de

\footnotetext{
${ }^{14}$ Como exemplo das empresas, grandes grupos internacionais e algumas nacionais listadas na Bolsa de Valores de São Paulo (BOVESPA), com sede em São Paulo, têm-se a Vanguarda Agro, Bünge, Bom Jesus, Amaggi, BRF, Louis Dreyfus, Bayer, Syngenta, entre outras.
} 
Otaviano Olavo Pivetta. Instalado no início dos anos 1980 em Lucas do Rio Verde, plantando arroz, soja e milho e, posteriormente, desenvolvendo a suinocultura, Pivetta adquire no município de Nova Mutum, em meados dos anos 1990, das terras da colonizadora Mutum Agropecuária S.A. (ainda baratas), $17 \mathrm{mil}$ ha, constituindo a Fazenda Ribeiro do Céu e fundando a Vanguarda Agropecuária do Brasil em 1998. Em 2011 o fundo Veremonte, do megainvestidor espanhol Enrique Bañuelos, que já havia adquirido o controle de outros dois grupos - a Brasil Ecodiesel (com foco na produção de biocombustível) e da Maeda Agroindustrial (empresa paulista com foco na produção de algodão e grãos) - incorpora a Vanguarda Agropecuária do Brasil, formando a maior empresa do agronegócio brasileiro: a Vanguarda Agro ${ }^{15}$. Este processo sinaliza como a monopolização da terra em Mato Grosso viabiliza a acumulação do campo e a formação de grandes empresas do agronegócio, que vão sendo sucessivamente fusionadas e adquirindo maior escala, inclusive através da sua crescente internacionalização ${ }^{16}$.

Os grandes grupos vêm controlando boa parte da logística de transportes em Mato Grosso, possuindo terminais de carga, entrepostos, silos etc. Além disso, vêm compondo juntamente com grandes famílias capitalizadas - os "pioneiros" enriquecidos - o que chamamos de um controle oligopolista da terra. É importante salientar que nem sempre estes grupos do agronegócio compram novas terras, lançando mão também de arrendamentos em terras de grandes famílias e de médios produtores, ou ainda, embora não seja o caso específico de Nova Mutum, de agricultores familiares ${ }^{17}$. Lembramos que Nova Mutum integra uma região já consolidada (cf. BERNARDES, 2006) da economia da soja, o que significa, de um lado, que já conta com uma densidade técnica e cadeias produtivas em avançado estágio de integração - como aquela representada pelas atividades da produção de grãos e sua integração com os frigoríficos, produtores de carnes processadas para consumo interno e exportação - mas, por outro lado, que também já produziram certo "esgotamento" das áreas de expansão das lavouras e uma valorização das terras que impele o avanço da fronteira para áreas mais a norte e em direção ao Parque Nacional do Xingu e ao Vale do Araguaia (Nova Ubiratã, Santiago do Norte, Querência, Confresa); sob elevado impacto na transformação fundiária e nas relações produtivas dos camponeses, sobretudo na região do Araguaia.

\footnotetext{
${ }^{15}$ Segundo informações contidas no sítio da Vanguarda-Agro, o grupo conta em 2015 com um total de 224 mil hectares de terras próprias e arrendadas, cujo foco é a produção de grão (soja e milho) e fibras (algodão), bem como a valorização das terras. Em Nova Mutum, o grupo possui a unidade de produção Ribeiro do Céu, com 30.670 hectares (12.548 ha próprios e 18.122 ha arrendados).

${ }^{16}$ Movimento similar pode ser observado pela compra do frigorífico Mary Loise, localizado em Nova Mutum, pela Perdigão, em 2005. Com a compra a Perdigão (BRF a partir de 2009) incorpora toda a capacidade de abate e de cria (que engloba estrutura de matrizes, incubatório, fábrica de ração, produtores integrados) do abatedouro local, ampliando tal capacidade, monopolizando o mercado e ligando-se ao capital internacional por meio da negociação de seus papéis na BOVESPA.

${ }^{17}$ Para uma compreensão das relações entre o agronegócio e a agricultura familiar, bem como para um debate das políticas públicas, ver os trabalhos de Wilkinson (2008) e Sauer (2008).
} 
Esta dinâmica territorial, que é ao mesmo tempo um processo de controle fundiário e econômico, possui também uma expressão no poder político, o que significa que governos, órgãos e instituições públicas locais e regionais têm sido influenciados pelos interesses hegemônicos das grandes corporações, pelas famílias mais abastadas do agronegócio e proprietárias de terras ${ }^{18}$, além, obviamente, do poder das colonizadoras ${ }^{19}$. Assim, cargos públicos vêm sendo frequentemente ocupados por representantes diretos dos setores latifundiários e do agronegócio, reproduzindo a indistinção entre o público e o privado que marca a história da sociabilidade e dos poderes políticos no Brasil, como evidenciam os trabalhos de Silva (2008) e de Martins (1999). O entrelaçamento entre terra e poder no Brasil é algo antigo, sendo a apropriação - muitas vezes ilegal - de grandes porções de terra um processo fundamental na constituição do próprio Estado brasileiro pelas elites agrárias, como demonstra Silva (2008). O trabalho de Castilho traz de modo contundente o fato de como governantes e políticos são também latifundiários no Brasil: “(...) Foi na Fazenda Santa Cruz (...) que Dom Pedro I comemorou a independência - e onde a princesa Isabel assinou a Lei Áurea. (...) Antônio da Silva Prado (...) primeiro prefeito de São Paulo, deputado, ministro, chegou a ter 24 milhões de pés de café. (...)" e acrescenta: "Getúlio Vargas era um pecuarista" (CASTILHO, 2012, p.20).

Esta aliança constitutiva entre terra e poder político no Brasil certamente não está desvinculado do poder econômico e seguramente não está restrita à realidade agrária, sendo também apoiada pela concentração da propriedade nas cidades, ou das melhores e mais caras localizações das cidades. A partir da década de 1980 é preciso acrescentar, ainda, novos elementos ao trinômio terra-poder-capital, que é a como a economia mundializada, o que significa que as elites locais irão alinhar-se aos interesses da reprodução dos capitais internacionais. Como afirma Oliveira (1995; 1997; 2007), trata-se da união entre o latifúndio e o capital (também internacional) possibilitada pelo agronegócio, que produz como condição e efeito da sua reprodução o poder político. O município de Nova Mutum reproduz tais fundamentos: basta lembrar que o atual prefeito de Nova Mutum, Adriano Xavier Pivetta (PDT), é também um dos acionistas da Vanguarda Agro. O mesmo ocorre

\footnotetext{
${ }^{18}$ A exemplo das famílias Campos e Maggi. A primeira se reveza há mais de seis décadas em cargos públicos eletivos: prefeitos (sobretudo em Várzea Grande), governadores, deputados federais e senadores. São também proprietários de redes de comunicação e pecuaristas. Júlio José de Campos era governador de Mato Grosso em 1994, ano da criação do município de Campos de Júlio, novo eixo de expansão da soja na BR-364. Blairo Maggi, que comanda o grupo Amaggi, foi governador de Mato Grosso (2003-2010) e atualmente é senador, além de produtor de soja, atuando nas regiões de Sapezal e Campo Novo do Parecis, de Querência e de Rondonópolis.

${ }^{19} \mathrm{O}$ poder local das colonizadoras é exercido, dentre outras maneiras, por meio de doações de terras para a edificação de órgãos públicos. Um exemplo disso é o terreno de $2 \mathrm{mil} \mathrm{m}^{2}$ onde se construiu a sede própria do Ministério Público do Estado de Mato Grosso em Nova Mutum, que foi doado pela Mutum Agropecuária S.A., de acordo com nota publicada pela Assessoria de Imprensa do órgão.
} 
com o seu irmão, Otaviano Olavo Pivetta, que é o atual prefeito de Lucas do Rio Verde $^{20}$.

Embora bastante nova a cidade já conta com problemas urbanos que procedem do seu projeto original e de seu forte crescimento, como é o caso dos armazéns de grãos localizados na rodovia em áreas centrais da cidade. No momento em que foi realizado o projeto de colonização essa infraestrutura serviu para a atração e concentração das atividades econômicas e instalação de empresas e outros equipamentos urbanos. Atualmente, entretanto, os armazéns ocupam grandes terrenos e causam uma série de transtornos aos moradores, entre eles: barulho, poeira e fumaça decorrentes da movimentação de carretas, a interrupção de vias etc. Interessante notar que, embora jovens, tais cidades contam com um dinamismo econômico e, sobretudo, urbano que faz rapidamente envelhecer aquilo que fora projetado duas décadas antes. Desenvolveram suas próprias contradições espaciais, no caso as do espaço urbano em relação à dinâmica do campo, como a necessidade de realocação das grandes infraestruturas agropecuárias que hoje permanecem ocupando grandes espaços em regiões centrais da cidade.

Outros conflitos são produzidos pela própria dinâmica de adensamento da cadeia produtiva dos grãos e carnes processadas (frigoríficos), que atrai grandes grupos que se instalam (com incentivos fiscais) no município, os quais necessitam de numerosa mão de obra desqualificada para a realização de atividades extremamente fatigantes e degradantes - abate, evisceração, embalagem de aves e suínos -, força de trabalho agenciada e transportada muitas vezes pelos mesmos frigoríficos de regiões e cidades mais pobres do país e de Mato Grosso até Nova Mutum. O rápido crescimento demográfico requer da municipalidade vultosos investimentos em infraestrutura, serviços e equipamentos urbanos - conjuntos habitacionais, postos de saúde, escolas, transporte, assistência social etc.

A expansão urbana antes da elaboração do PD vinha se dando, segundo as entrevistas realizadas, sobretudo através de loteamentos das fazendas próximas à cidade, processo que continua atualmente, porém de modo supostamente mais regulado. O "planejamento urbano" deve aqui ser relativizado, já que ele seguirá sendo, na sua essência, um empreendedorismo imobiliário privado ditado, sobretudo, pelos interesses da colonizadora e das principais famílias proprietárias. Acompanhando o processo de reelaboração do PD do município ao longo de 2014, perguntamos: qual é o sentido geral da nova proposta? Demandado principalmente pela prefeitura e executado por uma comissão técnica ${ }^{21}$, o PD Participativo,

\footnotetext{
${ }^{20}$ Otaviano Pivetta detém em 2015, segundo informações da BOVESPA, cerca de $12 \%$ das ações ordinárias do grupo, sendo também seu conselheiro de administração.

${ }^{21}$ Comissão composta por uma empresa de arquitetura (Ênio Luiz Perin Arquitetura e Urbanismo, com sede em Toledo-PR), pelo arquiteto da prefeitura (coordenador local da reelaboração do PD) e por servidores representantes de todas as secretarias municipais. A comissão elaborou "eixos temáticos" expostos à população nas reuniões. Segundo nos foi relatado, a maior parte das propostas 
embora leve essa designação, em grande medida reproduz os interesses de investidores e proprietários de terra ao expandir o perímetro urbano - de cerca de 9 mil hectares passando a inicialmente 14 mil e provavelmente a 18 mil hectares - e, com isso, fomentar a segurança jurídica das negociações em torno dos novos loteamentos bem como assegurar a valorização fundiária. Os técnicos responsáveis pelo PD projetam, para os próximos 20 anos, uma cidade de cerca de 150 mil habitantes.

Do ponto de vista urbanístico, o documento não traz inovações em termos de zoneamento, sendo inclusive refratário à concepção de usos mistos, justificando com isso a segregação socioespacial por meio de um traço supostamente natural e cultural dos grupos sociais, que seria dado, segundo nos foi dito, pelo fato de que "os iguais procuram sempre estar próximos". Existe a proposta de densificar o uso e a ocupação de áreas centrais e também outras orientações, entre as quais destacamos as propostas de base econômica 22 como "planejar e modernizar a gestão tributária municipal visando à melhoria da receita própria"; "promover e incentivar a base econômica municipal através de mecanismos fiscais e tributários"; "consolidar atividades industriais existentes"; "desenvolver projeto para implantar novo Distrito Industrial"; "promover o adensamento das cadeias produtivas regionais e investir em marketing local"; "implantar um novo Parque de Exposição"; "fomentar através de marketing e ampla divulgação o turismo tecnológico local”. Alguns desses itens nos chamam atenção na medida em que a municipalidade reconhece e assume a importância de se implantar um "Parque Tecnológico", ligado obviamente à tecnologia agropecuária, fazendo desta característica um elemento constitutivo de uma representação ideologizada do espaço, consumida por meio do turismo.

Para além da análise detalhada dos conteúdos do ordenamento econômico, social, ambiental, de mobilidade e territorial proposto pelo novo instrumento, sublinharemos a relação entre o planejamento urbano, o que denominamos oligopolização da produção do espaço. Nesse sentido, no dia anterior à realização da segunda e última audiência pública do PD reúnem-se no gabinete do prefeito algumas famílias com o intuito de formalizar uma doação de terras ao município: cerca de 300 ha. A seguir, a transcrição de trecho da ata dessa reunião (com os nomes dos doadores substituídos pelas iniciais):

(...) tratou-se do pedido feito pelo senhor prefeito municipal Adriano Xavier Pivetta de doação de áreas ao município de

da população girava em torno de "probleminhas que têm no bairro", o que demonstrava a necessidade de um projeto técnico e profissional, mas também participativo.

${ }^{22}$ Existe uma série de propostas sociais, ligadas a serviços de proteção social básica, de ampliação da rede de centros assistenciais, de capacitação profissional,entre outros. Também está prevista a reelaboração e continuidade da rede viária para o novo perímetro urbano, entre outras propostas aqui não mencionadas, como saneamento, iluminação etc. 
Nova Mutum, sem ônus à municipalidade (...) afim de garantir (...) um futuro pujante ao município (...). Após discussões (...) os senhores proprietários de áreas decidiram por DOAR ao município de Nova Mutum áreas de terras, sem ônus, exigências ou embaraços. Ficando acertado as seguintes quantidades de áreas que irão ingressar ao Patrimônio Público Municipal, por parte do Sr. V. C. B. 35,00 ha, F. P. M. 50,00 ha, N. C. 21,00 ha, J. G. 20,00 ha, J. R. 10,00 ha, e Mutum Agropecuária 150,00 ha de forma imediata e outros 50,00 ha em projeção futura (...). O município de Nova Mutum fica responsável pela implantação total da infraestrutura nas áreas recebidas em doação, e parceria de trinta por cento dos custos da infraestrutura de acesso às áreas recebidas [grifos nossos]. 


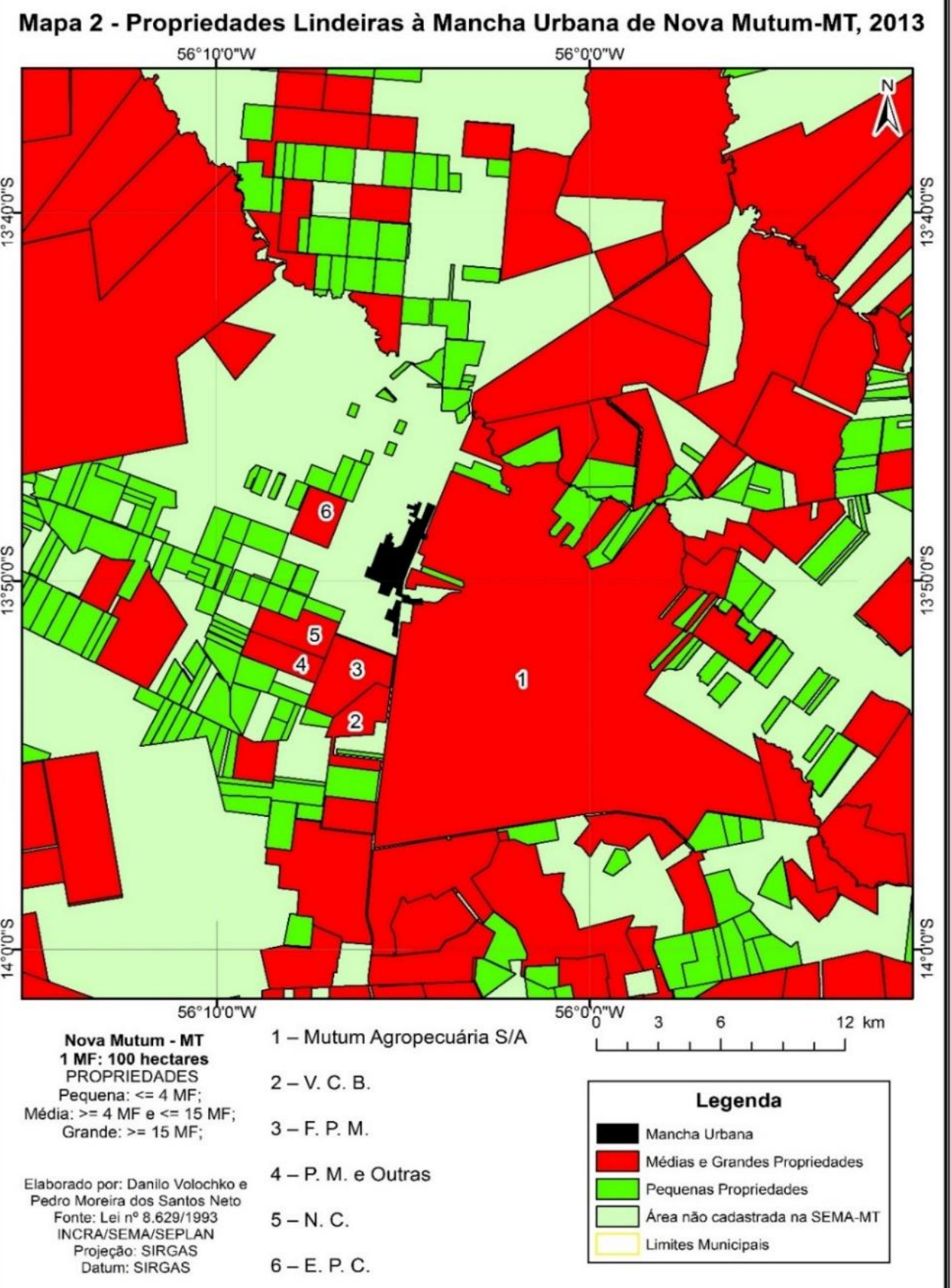


O Mapa 2 traz as propriedades limítrofes à mancha urbana, enumerando de 1 a 5 alguns proprietários (pelas iniciais dos seus nomes) de terras lindeiras ao perímetro urbano. A doação de terras ao município por parte de famílias proprietárias pode ser entendida como um gesto de incentivo ao desenvolvimento da cidade, mas parece se incorporar a uma estratégia de valorização das próprias terras pertencentes a tais famílias e à colonizadora, uma vez que a prefeitura se compromete a dotar de infraestrutura completa esses espaços, valorizando com investimentos públicos as áreas adjacentes igualmente pertencentes aos doadores. Além disso, trata-se de uma ação que consolida o poder de algumas famílias proprietárias. Veja-se nos Croquis 1 e 2 (sem legendas e escalas) a localização das áreas doadas (Croqui 2), sua relação com as propriedades representadas no Mapa 2 e a proposta de expansão do perímetro urbano.
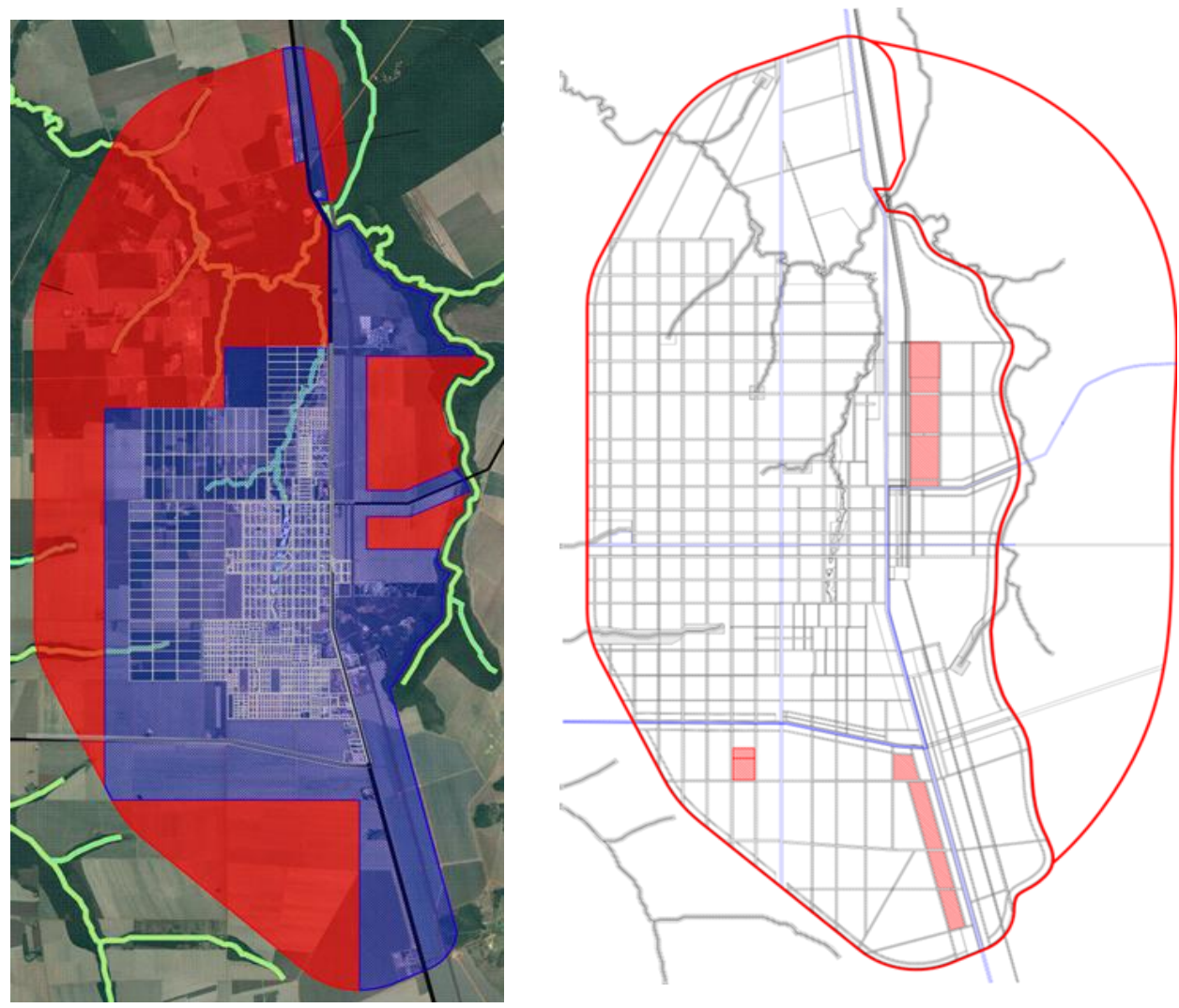

Croqui 1: Proposta de novo perímetro urbano. Croqui 2: Localização dos terrenos doados.

Fontes: Materiais fornecidos pela Prefeitura Municipal de Nova Mutum. 
Nota-se no Croqui 1 que a área em azul corresponde ao perímetro urbano atual e a área em vermelho à proposta de expansão. Vale mencionar que a primeira imagem resulta da apresentação feita na primeira audiência pública e a imagem da direita nos foi enviada com a Ata de doação, realizada em reunião um dia antes da segunda audiência pública. No Croqui 2 vemos que a linha vermelha que representa o perímetro é maior, embora efetivamente a proposta aprovada corresponda quase que totalmente ao Croqui 1 . As áreas doadas são contíguas à expansão do perímetro e serão objeto de dotação de infraestruturas pela municipalidade e posterior valorização do "restante" dos terrenos dos doadores proprietários, beneficiando em grande medida os interesses privados desses proprietários.

A Imagem 1 traz, na porção central superior, uma seta azul indicando perímetro na mesma cor onde localiza-se a prefeitura, a norte do centro da cidade; uma seta amarela mostra a localização das 500 moradias construídas pela Perdigão (depois BRF) por meio do Programa Prohab, para alojar seus trabalhadores; uma seta vermelha que mostra a localização da BRF e uma que indica o conjunto popular Residencial das Palmeiras. A observação permite constatar que uma indústria (a BRF) está mais bem localizada que alguns bairros.

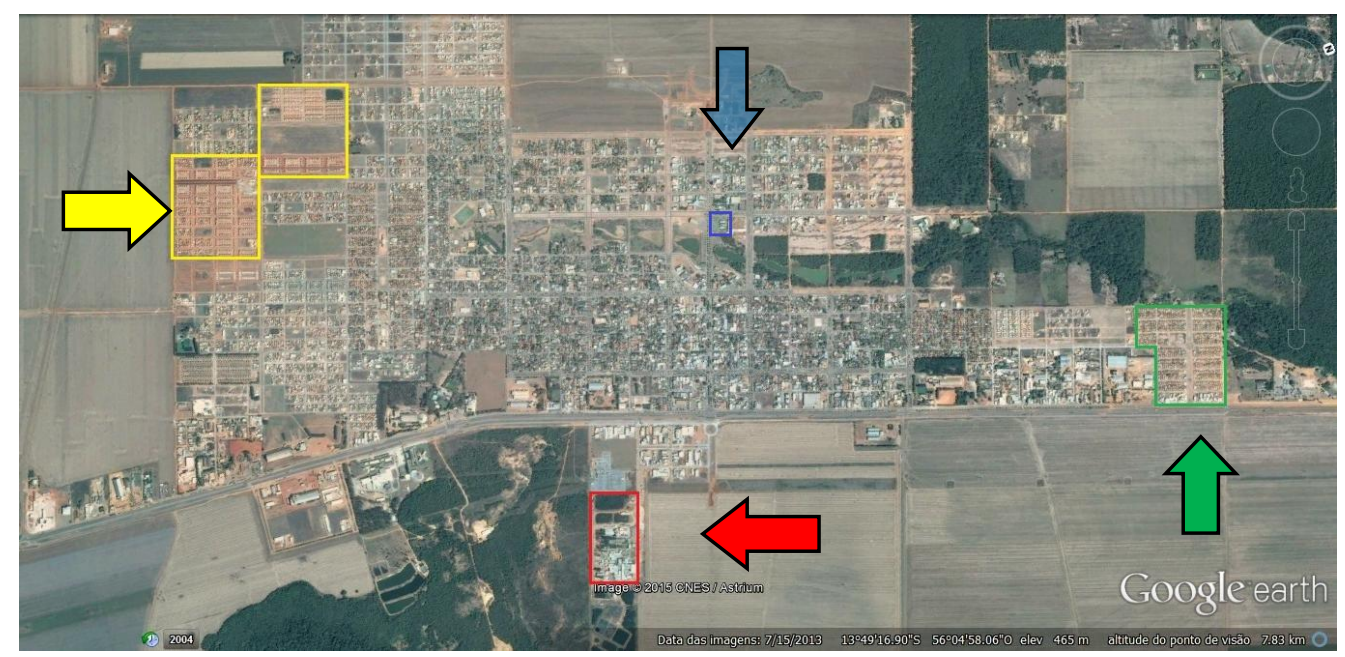

Imagem 1: Nova Mutum - Prohab Perdigão, BRF, Prefeitura e Residencial das Palmeiras. Fonte: programa GoogleEarth. Acesso em 09 set. 2015.

Elaboração: Danilo Volochko. 


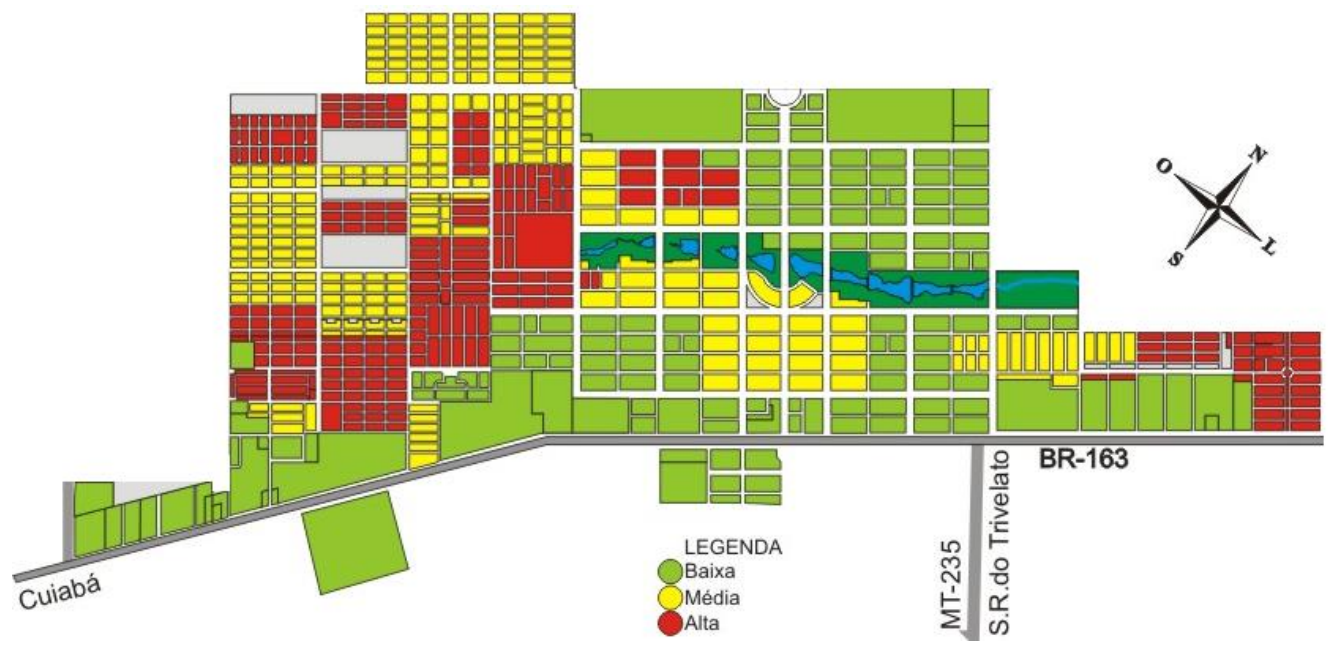

Imagem 2: Densidade demográfica em Nova Mutum.

Fonte: Prefeitura Municipal de Nova Mutum.

A Imagem 2 traz a densidade demográfica, que ajuda a complementar a caracterização inicial da periferização e da segregação socioespacial em Nova Mutum.

\section{Para uma crítica da prática socioespacial das "cidades do agronegócio"}

Em que medida o processo de expansão urbana analisado não é algo recorrente na urbanização brasileira? Parece não existir muita novidade nesses tipos de ação, porém, o que buscamos analisar é que num contexto de elevada concentração fundiária - como é o caso de Nova Mutum - não existiria, como afirma Oliveira (1997), uma disputa acirrada pela terra no interior de um processo concorrencial; a novidade estaria justamente num controle relativamente maior da produção e reprodução do espaço urbano por parte de poucos grupos e famílias, articulando-se a este poder político-territorial o poder econômico financeirizado do agronegócio, que consolida a oligopolização das dinâmicas de produção no campo e que participa das decisões e interesses na produção do espaço urbano. Além disso, nessa realidade particular há uma fusão tendencial entre a terra, o capital e o Estado nas mãos de poucas empresas, famílias e governantes que concentram estes elementos.

A pesquisa até aqui desenvolvida nos forneceu elementos para pensar o modo como se reproduzem, no espaço intraurbano da região dominada pelo agronegócio 
na BR-163 mato-grossense, algumas relações entre os sujeitos sociais a partir do caso representado pela cidade de Nova Mutum. Não obstante às particularidades sempre presentes em qualquer estudo de caso, pensamos que ele pode nos remeter à exacerbação de um sentido comum da história fundiária brasileira, pautada na concentração da terra. No mínimo, pensamos que o processo em tela permite refletir sobre os desdobramentos da reprodução do espaço urbano e rural em contextos de expansão do agronegócio no Brasil, o que ajudaria a entender vieses e particularidades da relação terra-poder-capital no Centro-Oeste, na região do MAPITOBA - Maranhão, Piauí, Tocantins e Bahia -, no sul do Pará e em Rondônia.

O controle oligopolizado da terra, do poder político e do poder econômico nas mãos de grandes empresas e de algumas famílias, impõe enormes desafios para as formas populares e emancipatórias de apropriação do espaço, seja nas cidades ou no campo, no sentido de que tal processo aprofunda mecanismos como a valorização do espaço urbano e rural, contribuindo para o cerco e destituição do território da agricultura familiar camponesa e precarizando as formas de acesso à moradia e à cidade pelos trabalhadores pobres, segregados economicamente e tendo muitas vezes sua cultura e origem negadas, marginalizados do ponto de vista socioespacial e da vida urbana, mas incluídos precariamente na necessária realização da economia "moderna" articuladora do campo e da cidade.

O estudo da produção do espaço a partir da dimensão da vida cotidiana, aquela do modo de vida e de trabalho, permitiu-nos conhecer práticas como a ida dos trabalhadores das fazendas para a cidade no início do mês para o recebimento de seus salários como um momento de festa, de fazer compras no mercado e de comprar pequenos eletrodomésticos, de comer e beber com os amigos e companheiros antes de voltarem às fazendas e retornarem à cidade no mês seguinte; ou então a vida em quitinetes e cortiços na cidade denotando os elevados custos da terra e do aluguel, mesmo nos conjuntos habitacionais; a perspectiva de migrar a qualquer tempo para o trabalho em outra cidade ou fazenda; o cerceamento do direito de ir e vir, de permanecer, com a prática comum de compra de passagens para o retorno à cidade natal, enfim, toda a sociabilidade de uma população tolerada enquanto prestadora de serviços básicos, muitas vezes temporários: vendedores, empregadas domésticas, motoristas, trabalhadores da construção, dos frigoríficos etc.

Além de contribuir para o desvendamento das representações hegemônicas do espaço urbano dessas cidades tidas e como bem planejadas e modelos a serem seguidos, a crítica da vida cotidiana e das formas de sociabilidade - pesquisa que ainda necessita ser aprofundada - torna-se fundamental para a compreensão mais ampla e profunda de uma realidade que produz dialeticamente o espaço e o tempo do novo reproduzindo o espaço e o tempo do arcaico, sob o fundamento da desigualdade socioespacial capitalista. 


\section{Bibliografia}

ARRUDA, Z. A. (2007) Onde está o agro deste negócio? Tese (Doutorado em Geografia) - Instituto de Geociências, Universidade Estadual de Campinas. Campinas.

BERNARDES, J. A.; FREIRE FILHO, O. de L. (orgs.). (2006) Geografias da Soja: BR-163: Fronteiras em Mutação. Rio de Janeiro: Arquimedes Edições.

CASTILHO, A. L. (2012) Partido da terra: como os políticos conquistam o território brasileiro. São Paulo: Contexto.

CUNHA, J. M. P. da. (2006) Dinâmica migratória e o processo de ocupação do Centro-Oeste brasileiro: o caso de Mato Grosso. São Paulo: Rev. bras. estud. popul., v. 23, $\mathrm{n}^{\mathrm{o}}$ 1. pp. 87-107. Disponível em: http://www.scielo.br/scielo.php?script=sci_arttext\&pid=S0102-

30982006000100006\&lng=en\&nrm=iso. Acessado em: 24 abr. 2015.

DAVIS, J. H; GOLDEBERG, R. A. (1957) A concept of agribusiness. Boston: Division of Research, Graduate School of Business Administration, Harvard University.

ELIAS, D. (2006) Globalização e fragmentação do espaço agrícola no Brasil. Nova Revista Eletrónica de Geografía y Ciencias Sociales, Universidad de Barcelona, vol. X, nº 218 (03). Barcelona: Scripta

GIRARDI, E. P. (2008) Proposição teórico-metodológica de uma Cartografia Geográfica Crítica e sua aplicação no desenvolvimento do Atlas da Questão Agrária Brasileira. Tese (Doutorado em Geografia) - Faculdade de Ciências e Tecnologia, Universidade Estadual Paulista. Presidente Prudente. Disponível em: http://repositorio.unesp.br/bitstream/handle/11449/105064/girardi_ep_dr_prud.pdf ?sequence=1\&isAllowed=y. Acessado em: 07 nov. 2015.

MARTINS, J. de S. (1999) O Poder do Atraso: Ensaios de Sociologia da História Lenta. São Paulo: Editora Hucitec.

. (2012) Fronteira: A degradação do outro nos confins do humano. São

Paulo: Contexto.

MORENO, G. (2007) Terra e Poder em Mato Grosso: Política e Mecanismos de Burla 1892-1992. Cuiabá: EdUFMT/Entrelinhas/FAPEMAT.

OLIVEIRA, A. U. de. (1995) Amazônia: monopólio, expropriação e conflitos. Campinas: Papirus.

(1997) A fronteira amazônica mato-grossense: grilagem, corrupção e violência. Tese (Livre-Docência) - Faculdade de Filosofia, Letras e Ciências Humanas. São Paulo.

. (2007) Modo capitalista de produção, agricultura e reforma agrária. São Paulo: FFLCH/Labur Edições.

ROMANCINI, S. R. (org.). (2009) Novas Territorialidades nas Cidades MatoGrossenses. Cuiabá: EdUFMT. 
SANTOS, M.; SILVEIRA, M. L. (2011) O Brasil: território e sociedade no início do século XXI. Rio de Janeiro: Record.

SAUER, S. (2008) Agricultura familiar versus agronegócio: a dinâmica sociopolítica do campo brasileiro. Brasília: Embrapa Informação Tecnológica.

SCHAEFER, J. R. (2002) Nova Mutum: história e fundação. Nova Mutum: Conselho Municipal de Cultura de Nova Mutum, Secretaria de Estado de Cultura, Lei de Incentivo à Cultura/ Conselho Estadual de Cultura, Governo de Mato Grosso.

SEABRA, O. C. de L.; MARTINS, S. M. M. (1993) A cidade sem infância no universo pioneiro da soja. São Paulo: Revista Travessia (15), ano VI, CEM.

SILVA, J. G. (1996) A nova dinâmica da agricultura brasileira. Campinas: Unicamp-IE.

SILVA, L. O. (2008) Terras devolutas e latifúndio: efeitos da lei de 1850. Campinas: Editora Unicamp.

SOUZA, A. M. de. (2007) Relatos da Cidade: nomadismo, territorialidades urbanas e imprensa. Cuiabá: Entrelinhas: EdUFMT.

WILKINSON, J. (2008) Mercados, redes e valores: o novo mundo da agricultura familiar. Porto Alegre: Editora da UFRGS.

Sites consultados

VANGUARDA AGRO. Disponível em: $\leq$ http://www.vagro.com.br/vanguardaagro/web/default_pt.asp?idioma $=0 \&$ conta $=28>$. Acessado em: 08 nov. 2015.

GRUPO RIVEIRO PARTICIPAÇÕES. Disponível em: <http://www.grpart.com.br/>. Acessado em: 08 nov. 2015.

MINISTÉRIO PÚBLICO DO ESTADO DE MATO GROSSO. Disponível em: $<$ https://www.mpmt.mp.br/imprime.php?cid=41305\&sid=58>. Acessado em: 08 nov. 2015. 